\title{
Economic and productivity comparison of ground support for rockburst-prone and squeezing ground conditions
}

\author{
LJ Hayman Coffey International Ltd, Australia
}

\begin{abstract}
Rockbursting and squeezing ground conditions in hard rock underground mines worldwide cause mine workers to be exposed to high consequence workplace hazards and have major economic implications. Designing ground support to withstand the anticipated ground conditions is one method of controlling these risks.
\end{abstract}

A rockburst is defined as damage to an excavation that occurs in a sudden and violent manner and is associated with a mining-induced seismic event, and may cause an unacceptable workplace hazard (Kaiser \& Cai 2013). Additionally, large scale deformations in drives, or squeezing ground conditions in hard rock underground mines have major economic implications. In 254 rockburst cases analysed worldwide by Heal (2010), the most common component of the integrated ground support system to fail was the surface support. It has also been suggested by Hadjigeorgiou et al. (2013) that squeezing ground cannot be stopped but can be controlled by ground support which is able to "deform in order to accommodate the resulting high deformations while maintaining the integrity of the reinforced rock unit" (Potvin \& Hadjigeorgiou 2008).

The Australian Centre of Geomechanics (ACG) has developed, over seven years a high energy absorption mesh (HEA Mesh) which is designed to withstand a larger amount of quasi-static and dynamic loading due to rockbursting and squeezing ground than regular weld mesh. It consists of a sheet of weld mesh reinforced with a cable around the sheet perimeter and interlocking in two ' $V$ ' shapes in the middle. The design was based upon the South African cable lacing method, but with the installation time of weld mesh, to combine strength and flexibility. Preliminary laboratory and field testing results indicate that the HEA Mesh included in a dynamic ground support system performs better than ground support that is commonly used currently for rockbursting and squeezing ground conditions. Underground operations have been reluctant to adopt this mesh due to lack of awareness of the product.

The literature will be used as a foundation to present laboratory and field test results of the HEA Mesh. Three case studies of Australian and European underground mining operations will be analysed for cost-benefit of incorporating HEA Mesh into their current rockburst and squeezing ground support.

Incorporation of the HEA Mesh was assessed and quantified to provide apparent cost savings in three currently operating underground mines. These study results offer a number of advantages to operations worldwide, including improved productivity and safety. In the current Australian mining climate specifically, cost savings would be extremely beneficial.

\section{Introduction}

Underground mining, in most cases, requires ground support to ensure excavations are stable to facilitate the extraction of ore over a planned time frame. Ground support is designed based on the stress regime; rock strength, rock structure, rock conditions and class of a particular area in the underground mine. It is a relatively costly part of the mining cycle; especially when the ground support is inadequate for the conditions and rockfalls or squeezing ground occurs, rendering the drive unserviceable. Ground support falls into two categories, ground reinforcement and surface support. Ground reinforcement includes the installation of rockbolts or tendons into the rock mass thereby improving the strength of the rock mass in 
the periphery of the excavation. There are many different types of rockbolts on the market and each works differently and is appropriate for specific ground conditions. Surface support includes the application of reinforcement to the excavation profile surface, and includes fibrecrete, weld mesh, cable lacing, mesh straps and thin spray on liners (TSLS). These elements have the purpose of containing blast damaged and stress induced damaged blocky material on the periphery of the excavation. They have the added bonus of creating an even surface for faster rock bolt installation.

High stress conditions, brittle rock and fault structures present in a mine may cause seismicity, which can manifest as rockbursting. If the ground support is inadequate for the energy created by the rockburst, the ground support will fail and pose a risk to personnel, equipment, and will require costly rehabilitation of the failed ground support. High stress conditions in relatively broken ground can cause convergence of the excavation, called squeezing ground. This also causes issues whereby the equipment can no longer fit through the drive, rendering the drive unserviceable. Stripping of the converged walls is then required and installing ground support for a second time.

In a mine where significant seismicity is experienced, to the extent where rockburst damage is caused to underground workings, the mine site will implement ground support designs which account for the possibility of dynamic loading. Under dynamic loading, it is expected that the load is transferred from the rock mass, to the bolts and surface support. To withstand the dynamic loading generated during a seismic event, the ground support must work as an integrated system and will only be as strong as its weakest link. In work done by Heal (2010), in which 254 cases of rockburst damage were analysed, it was demonstrated that the most common weakest link in the failed ground support system was the surface support.

The HEA Mesh was invented in 2006 and was developed by the ACG at The University of Western Australia (UWA). It was designed to provide superior rockburst and squeezing ground surface ground support, in order to reduce the risk and severity of rockfalls in underground mines with high stress and/or seismic conditions. The principle behind the HEA Mesh design is the South African cable lacing method, which has been proven to provide more effective rockburst containment under dynamic testing in comparison with other surface support methods, but is very time and labour intensive. In addition, the mesh has been designed to have the same installation time as a sheet of weld mesh.

The HEA Mesh consists of a regular sheet of weld mesh with an area $2.4 \times 3 \mathrm{~m}$, which is reinforced on the perimeter and interlinked in the middle by a cable, but it can be manufactured to any specified dimensions. In order for the HEA Mesh to work to its full capacity, it must be paired with dynamic rockbolts which are placed to ensure contact with the cable (Figure 1). UWA has entered into an agreement with DYWIDAGSystems International (DSI) to bring the product to market.

The intended target market for the HEA Mesh is underground mines requiring dynamic support, and who commonly use weld mesh combined with fibrecrete and rockbolts. Potentially, the current dynamic ground support regime is able to be replaced by HEA Mesh with rockbolts, and the saving from the elimination of fibrecrete should more than make up for the increased cost of HEA Mesh versus regular weld mesh. The current worldwide market for this product was analysed and quantified.

\subsection{HEA Mesh specifications}

The specifications of the HEA Mesh are as follows:

- A piece of weld mesh of size $2.4 \times 3.0 \mathrm{~m}$, with an aperture $100 \times 100 \mathrm{~mm}$ (can be manufactured to any dimensions).

- Wire diameter of $5.6 \mathrm{~mm}$.

- Mass per sheet is $45.5 \mathrm{~kg}$.

- Cable strand diameter is $12.7 \mathrm{~mm}$

- Cable tensile strength is $1,870 \mathrm{kN} / 18 \mathrm{t}$. 
- There are six barrels clamping the cable to the mesh.

Figure 1 illustrates the design of the HEA Mesh and the correct placement of rockbolts to allow the mesh to work to full capacity.

HEA Mesh is a standard sheet of weld mesh, with an attached steel cable. It is designed to overlap between neighbouring sheets, and the end result is the equivalent to the cable lacing solution: weld mesh supported by a continuous web of steel cable anchored by rockbolts. It is installed using a jumbo, exactly the same way as a normal sheet of weld mesh is installed in mines.
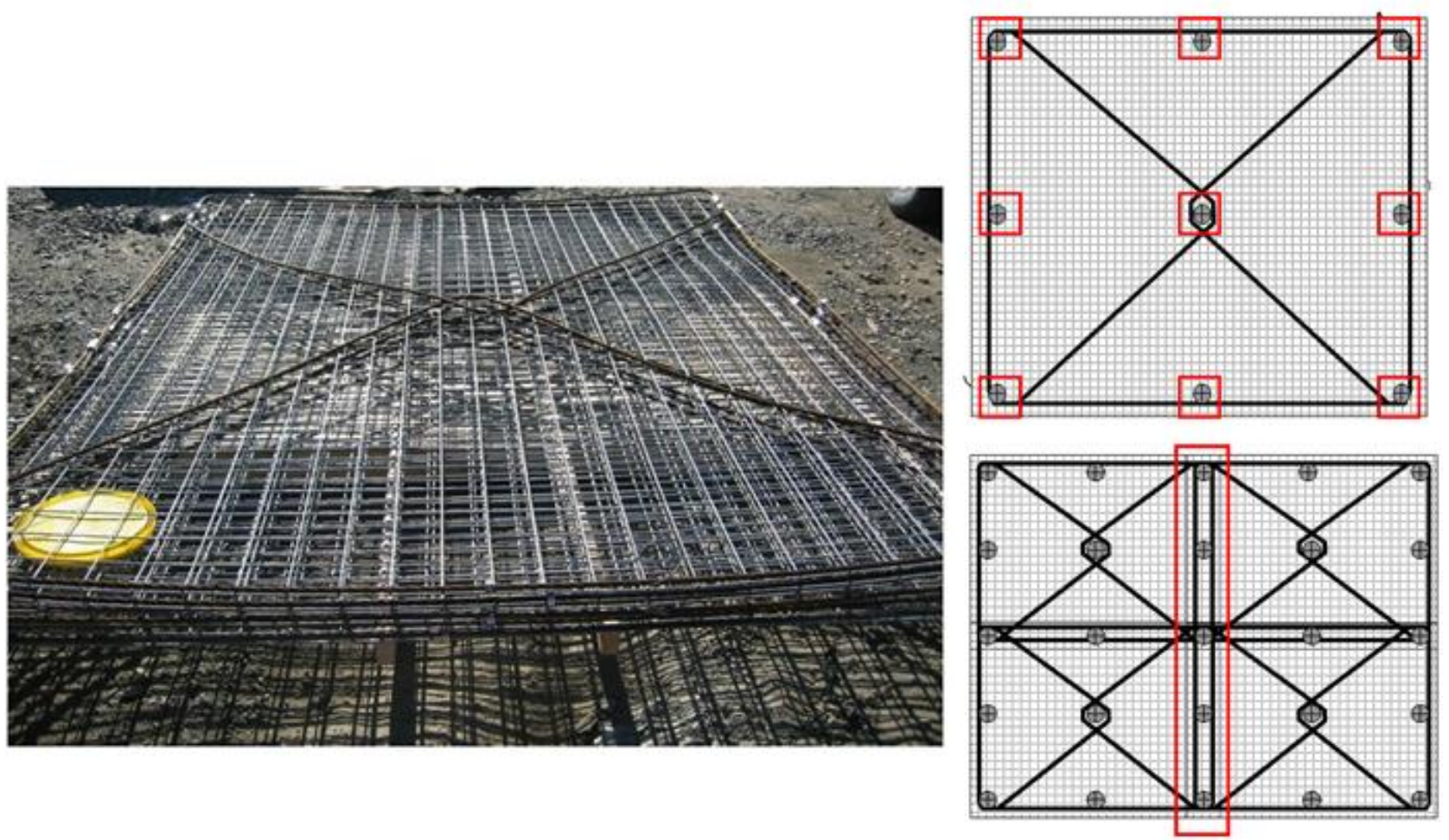

Figure 1 HEA Mesh design (Potvin, pers. comm., 29 October 2013)

\subsection{Cable lacing technique}

Mines in South Africa have been using cable lacing, or rope lacing, for many years to mitigate rockburst risks. However, this method is very costly and labour intensive.

Stacey and Ortlepp (2001) have tested the various surface ground support technologies using a dynamic drop test; refer to Figure 2 for results. This is used to simulate rockbursting conditions. The graph shows the deformation capacity ( $\mathrm{Y}$ axis) versus the energy absorption capacity ( $\mathrm{X}$ axis).

Cable lacing can sustain large deformations without breaking and absorb more energy from a rockburst ejection. The results show the superior performance (top right corner of the graph) when cable lacing is used (with weld mesh) compared to weld mesh alone and also weld mesh and fibrecrete combined.

These experimental results supplement the plethora of field evidence in South African mines illustrating that rope lacing is a superior support system due to the enhanced surface support capacity, which is the part of the support system that generally fails during a rockburst. 


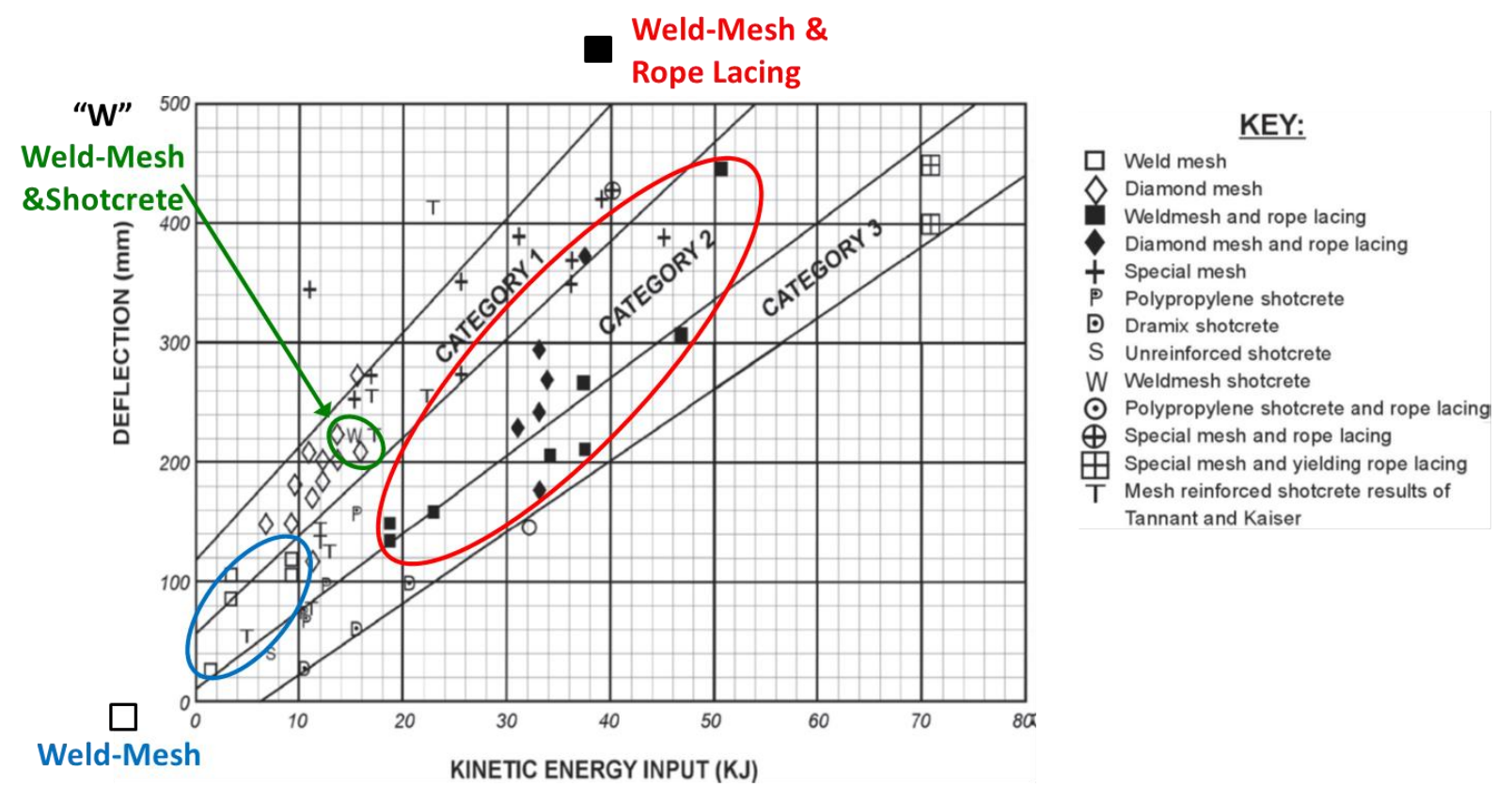

Figure 2 Results of dynamic testing of surface support liners (Stacey \& Ortlepp 2001)

\subsection{Testing and validation of HEA Mesh}

\subsubsection{Static laboratory testing}

The HEA Mesh has been tested in quasi-static (slow loading) conditions in the laboratory of UWA, shown in Figure 3. The results show that the mesh can take a point load of $14 \mathrm{t}$ in the centre and deform $700 \mathrm{~mm}$ before failing, which is more than two times the capacity of weld mesh or fibrecrete alone, which can deform $307 \mathrm{~mm}$ prior to failure (Morton et al. 2009).

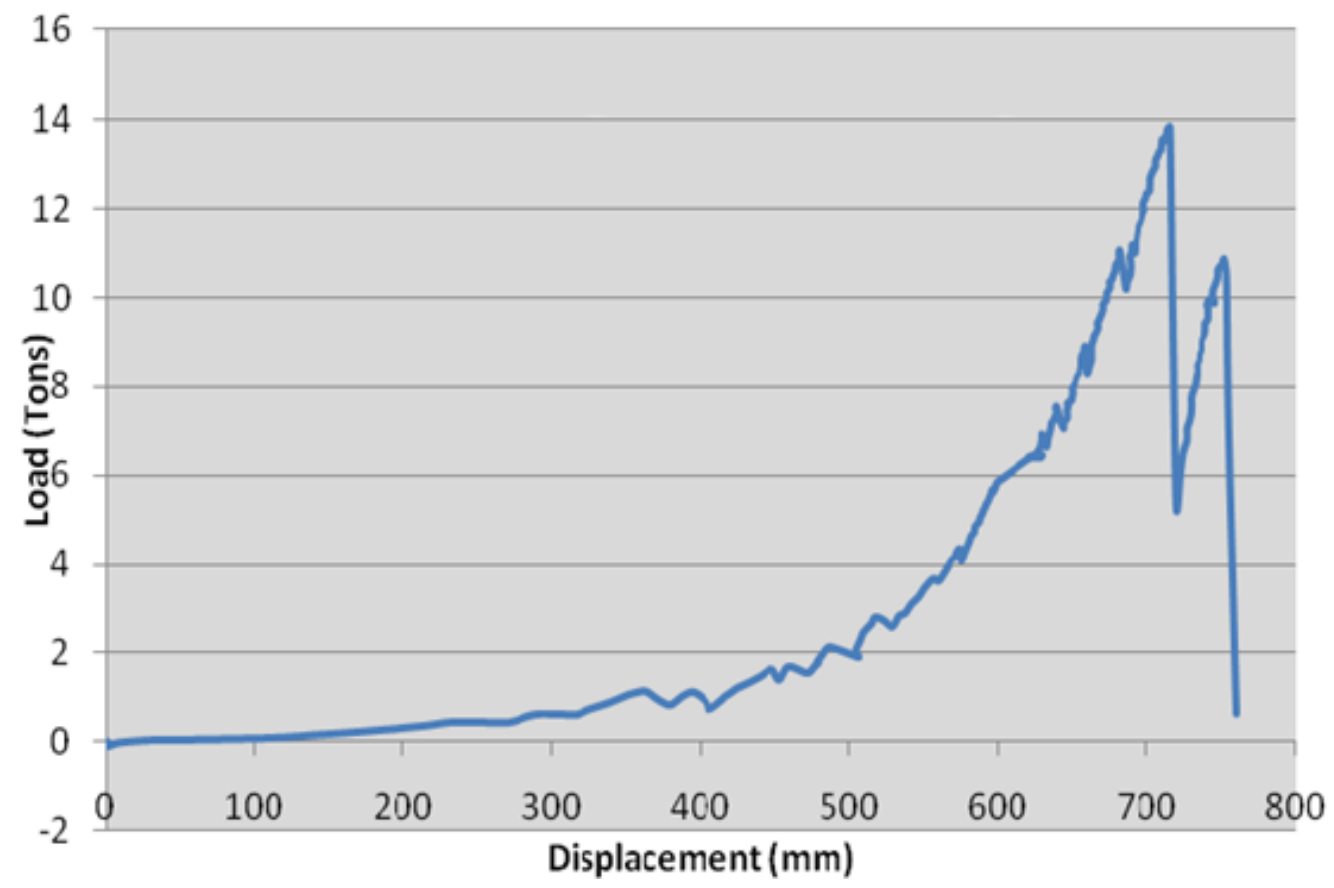

Figure 3 Quasi-static laboratory testing of HEA Mesh load displacement graph (Potvin, pers. comm., 29 October 2013) 


\subsubsection{Installation trial}

One full cut of five sheets HEA Mesh was installed at a metalliferous underground Australian mine by an experienced jumbo operator. The mesh sheets were of $2.4 \times 3 \mathrm{~m}$ size and the ground support rings were at $1.1 \mathrm{~m}$ spacings. The outcomes of the trial were as follows:

- The HEA Mesh was very easy to manipulate and install using a jumbo.

- The manual handling of the mesh was said to be easy despite the extra weight from the cable. The HEA Mesh does not have a strong tendency to bend when being carried.

- The installation time was between two and three hours for one full cut. The jumbo operator stated that he believed that the HEA Mesh was as easy to install as a regular weld mesh and, in a production environment, he would expect to obtain similar productivity in installing HEA Mesh as he did for installing weld mesh.

\subsubsection{Simulated rockburst testing}

As part of the research and development programme of the HEA Mesh at UWA, a rockburst was simulated using explosives.

Explosives were installed in three sets of blast holes installed behind the wall. The wall was surveyed with Sirovision before and after the blast, numerous geophones captured velocity of ejected rock along with a video capture of the event. Figure 4 shows a location map of the test site set-up.

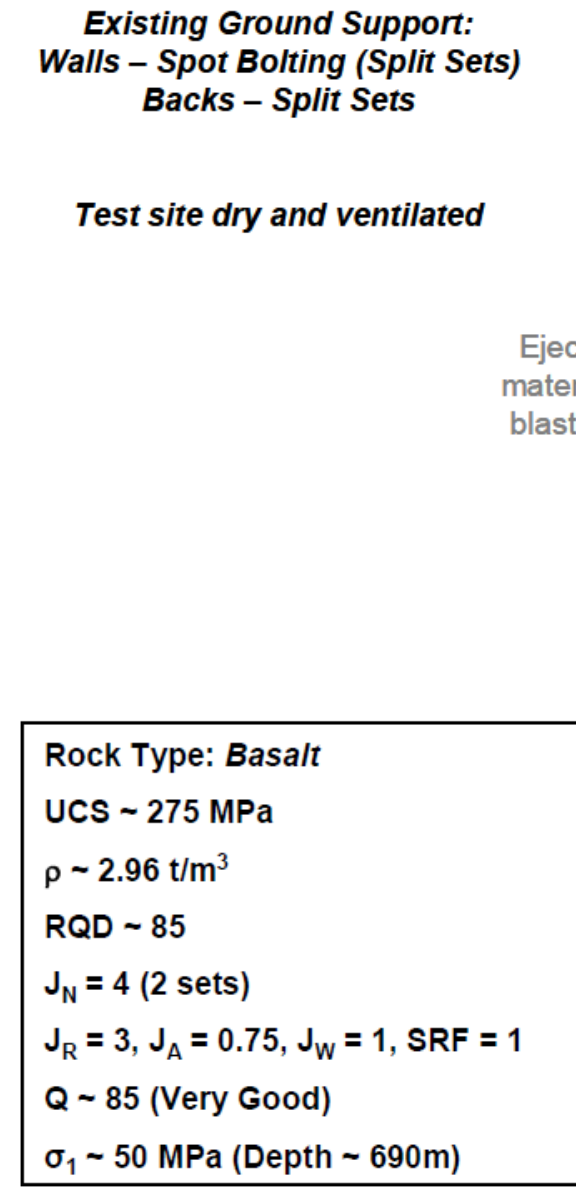

\author{
)
}

(1)

Test site dry and ventilated
\begin{tabular}{|l} 
majecte \\
blast
\end{tabular}
\begin{tabular}{|l} 
Rock Type: Basalt \\
UcS $\sim 275 \mathrm{MPa}$ \\
$\rho \sim 2.96 \mathrm{t} / \mathrm{m}^{3}$ \\
$\mathrm{RQD} \sim 85$ \\
$\mathrm{~J}_{\mathrm{N}}=4(2 \mathrm{sets})$ \\
$\mathrm{J}_{\mathrm{R}}=3, \mathrm{~J}_{\mathrm{A}}=0.75, \mathrm{~J}_{\mathrm{W}}=1, \mathrm{SRF}=1$ \\
$Q \sim 85($ Very Good $)$ \\
$\sigma_{1} \sim 50 \mathrm{MPa}$ (Depth $\left.\sim 690 \mathrm{~m}\right)$ \\
\hline
\end{tabular}

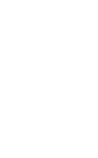

\section{Figure 4 Location map of simulated rockburst testing, (Australian Centre for Geomechanics [ACG] 2008)}

Cone bolts and HEA Mesh were installed on the left side of the test wall (Figure 5). 
Cone bolts, weld mesh and fibrecrete (including $70 \mathrm{~mm}$ Synmix synthetic fibres) were installed on the right side, this support being similar to the dynamic/seismic support commonly used in Australian mines. The synthetic fibre dosage used in the support system on the right was not documented.

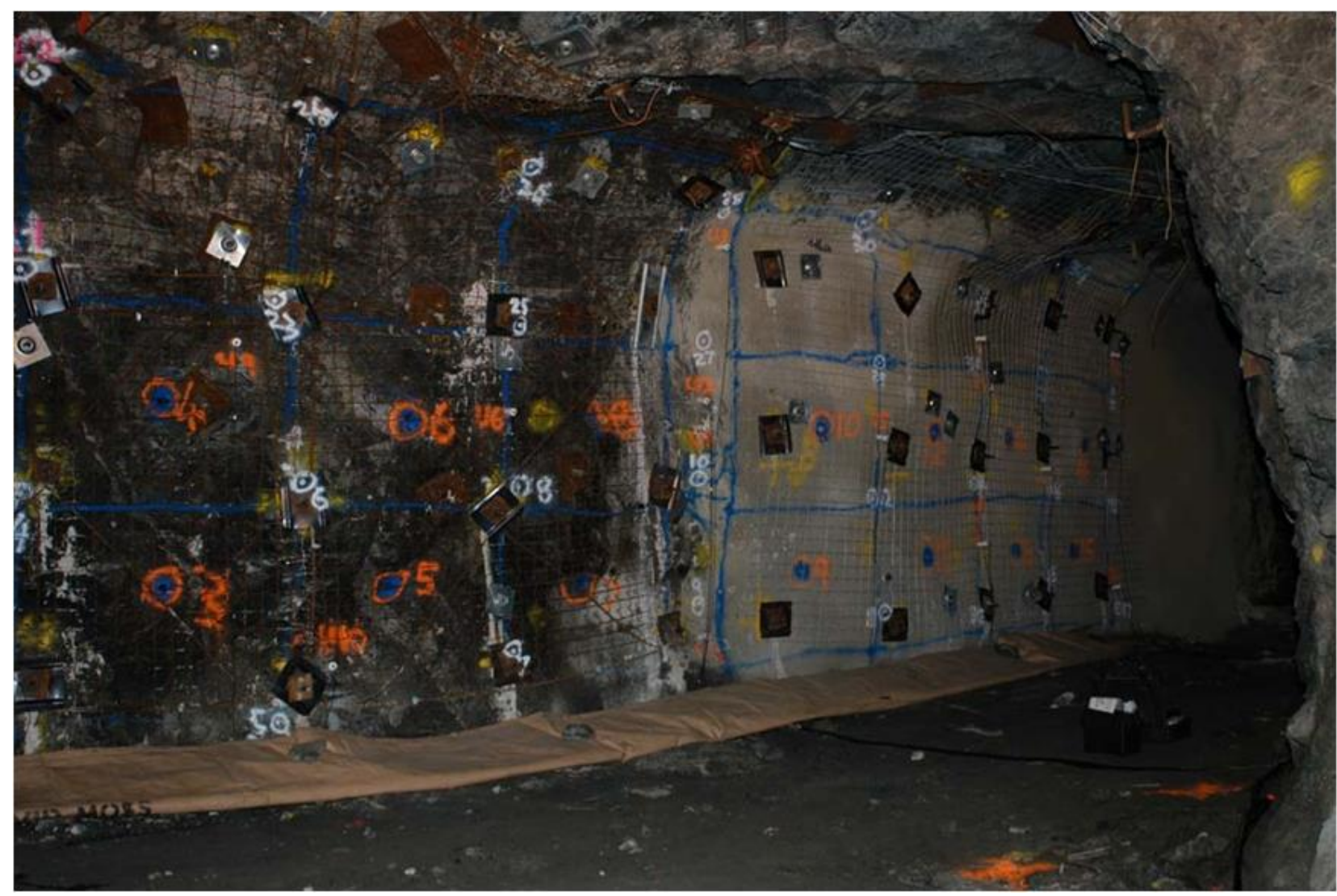

\section{Figure 5 Simulated rockburst testing ground support, (ACG 2008)}

The data from the geophones allowed the peak particle velocity (ppv) during the simulated rockburst to be reconstructed, (Figure 6). It is pertinent to appreciate the limitations of a rockburst simulation using blasting. Blasting creates a smaller seismic moment and significantly different P-waves than rockbursts. The ppv was concentrated in the bottom centre of the wall installed with HEA Mesh.

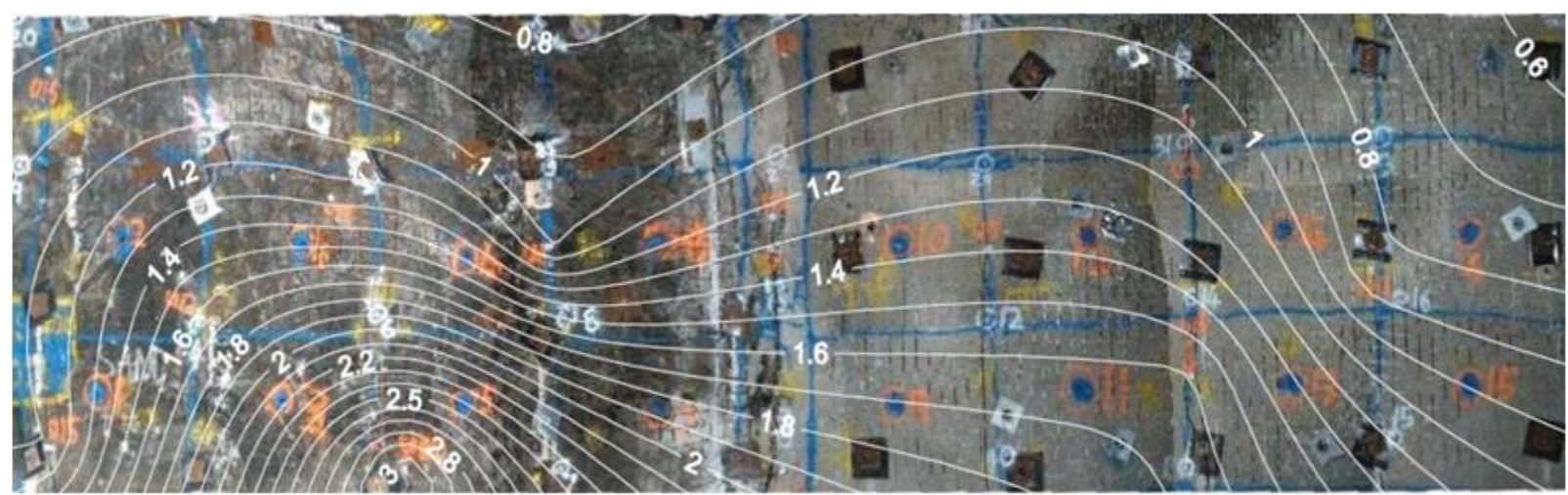

Figure 6 Simulated rockburst testing ppv contours (m/s), (ACG 2008) 
Observations from the simulated rockburst showed that the HEA Mesh sheets remained laced together. In the post-test photograph the HEA Mesh sheets opened as a single unit, like a door, (Figure 7). In doing this, the mesh pulled out many of the rockbolts (see red circle, bottom right of Figure 7). In this case, the HEA Mesh transferred the load to the rockbolts in which the grout strength was inadequate, and was not strong enough to hold the ejecting rock mass. In areas where the rockbolts held, the HEA Mesh also held.

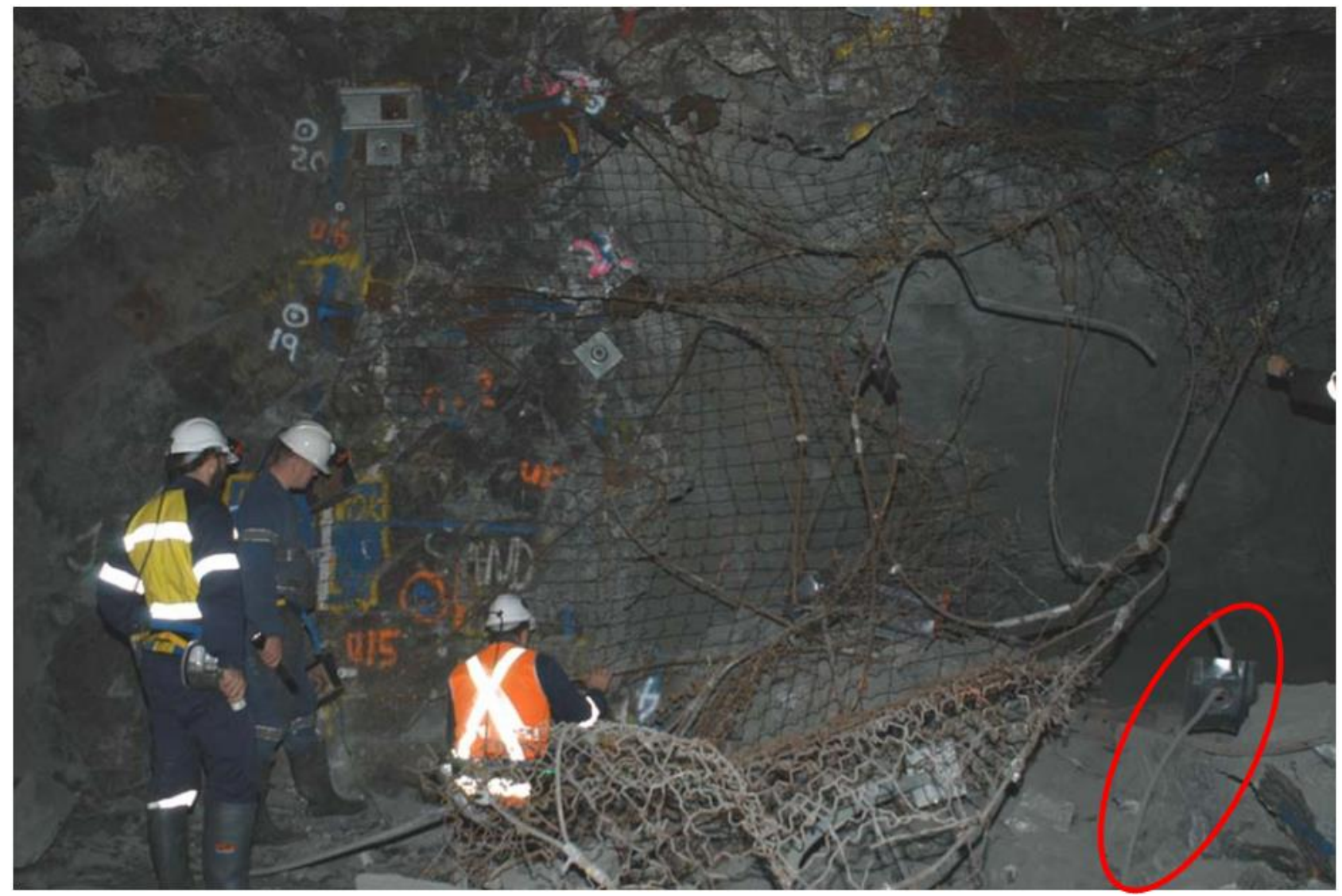

Figure 7 Post-rockburst simulation photo of HEA Mesh, (ACG 2008)

The damage was categorised according to the support damage scale from observations, after Kaiser et al. (1992). Moderate damage to ground support, showing significant loading and local loss of functionality is classified as S3. This category of damage is noted as the point where rehabilitation is required. 
Table 1 Support damage scale (SDS) used in the rockburst experiments (Kaiser et al. 1992)

\begin{tabular}{|c|c|c|c|}
\hline Damage level & General description & Support damage & Shotcrete damage \\
\hline so & Conditions unchanged. & No new damage or loading. & No new damage or loading. \\
\hline S1 & $\begin{array}{l}\text { Support undamaged but } \\
\text { first signs of distress } \\
\text { detectable. }\end{array}$ & $\begin{array}{l}\text { No damage to any support } \\
\text { component. }\end{array}$ & $\begin{array}{l}\text { Shotcrete shows new } \\
\text { cracks, very fine or widely } \\
\text { distributed. }\end{array}$ \\
\hline S2 & $\begin{array}{l}\text { Slight damage to support. } \\
\text { Loading clearly evident but } \\
\text { full functionality } \\
\text { maintained. }\end{array}$ & $\begin{array}{l}\text { Plates and wooden washers } \\
\text { on some rockbolts are } \\
\text { deformed, showing loading } \\
\text { Individual strands in mesh } \\
\text { broken. Mesh bagged but } \\
\text { retains material well. }\end{array}$ & $\begin{array}{l}\text { Shotcrete cracked, minor } \\
\text { flakes dislodged. Shotcrete } \\
\text { is clearly taking load from } \\
\text { broken rock mass (mostly } \\
\text { drummy). }\end{array}$ \\
\hline S3 & $\begin{array}{l}\text { Moderate damage to } \\
\text { support. Support shows } \\
\text { significant loading and local } \\
\text { loss of functionality; } \\
\text { retaining function primarily } \\
\text { lost (except in laced or } \\
\text { shotcreted areas). }\end{array}$ & $\begin{array}{l}\text { Plates and wooden washers } \\
\text { on some rockbolts are } \\
\text { deformed, showing loading } \\
\text { Individual strands in mesh } \\
\text { broken. Mesh bagged but } \\
\text { retains material well. }\end{array}$ & $\begin{array}{l}\text { Shotcrete fractured, often } \\
\text { debonded from rock and/or } \\
\text { reinforcement. Major flakes } \\
\text { possibly dislodged. Holding } \\
\text { elements mostly intact. }\end{array}$ \\
\hline S4 & $\begin{array}{l}\text { Moderate damage to } \\
\text { support. Support shows } \\
\text { significant loading and local } \\
\text { loss of functionality; } \\
\text { retaining function primarily } \\
\text { lost (except in laced or } \\
\text { shotcreted areas). }\end{array}$ & $\begin{array}{l}\text { Mesh is often torn and } \\
\text { pulled over rockbolt plates; } \\
\text { if it did not fail, it is } \\
\text { substantially bagged (at } \\
\text { capacity). Many rockbolts } \\
\text { failed. Rock ejected } \\
\text { between support } \\
\text { components. Cable lacing is } \\
\text { heavily loaded with bagged } \\
\text { mesh. }\end{array}$ & $\begin{array}{l}\text { Shotcrete heavily fractured } \\
\text { and broken, often separated } \\
\text { from the rock mass with } \\
\text { pieces lying on the ground } \\
\text { or hanging from } \\
\text { reinforcement. Connections } \\
\text { to holding elements often } \\
\text { failed or holding elements } \\
\text { failed locally. }\end{array}$ \\
\hline S5 & $\begin{array}{l}\text { Severe damage to support. } \\
\text { Support retaining, holding, } \\
\text { and reinforcing functions } \\
\text { failed. }\end{array}$ & $\begin{array}{l}\text { Most ground support } \\
\text { components broken or } \\
\text { damaged. Most rockbolts } \\
\text { fail and rock peels off cable } \\
\text { bolts. Shotcrete non- } \\
\text { functional. Mesh without } \\
\text { cable lacing heavily torn and } \\
\text { damaged. Cable lacing } \\
\text { systems heavily stressed } \\
\text { and often failed. }\end{array}$ & $\begin{array}{l}\text { For damage level } 55 \text {, } \\
\text { shotcrete fails to be } \\
\text { functional and the left-hand } \\
\text { column applies. }\end{array}$ \\
\hline
\end{tabular}

No breaks in the HEA Mesh reinforcement cable were observed, despite it being heavily bent and deformed by up to $300 \mathrm{~mm}$. This indicates that the HEA Mesh shows good potential for providing high energy capacity in a rockburst-prone environment when a suitably strong and yielding reinforcing element is used. Areas where the ground support system was most heavily damaged coincided where the lacing was not tight around the cone bolts and a good overlap was not achieved.

The energy from the blast can be calculated for every square metre of the wall by estimating the mass (M) that has moved and the velocity (C) measured by the geophone, using $\mathrm{E}=\mathrm{MC}^{2}$. 
The damage to ground support can also be related to the energy the support has experienced. This then allows a direct comparison of their performances.

The damage coinciding with S3 occurred at an average of around $9 \mathrm{~kJ} / \mathrm{m}^{2}$ energy demand for the cone bolts and HEA Mesh support system (Figure 8). Figure 8 also illustrates that the damage was concentrated in the part of the wall fitted with HEA Mesh.

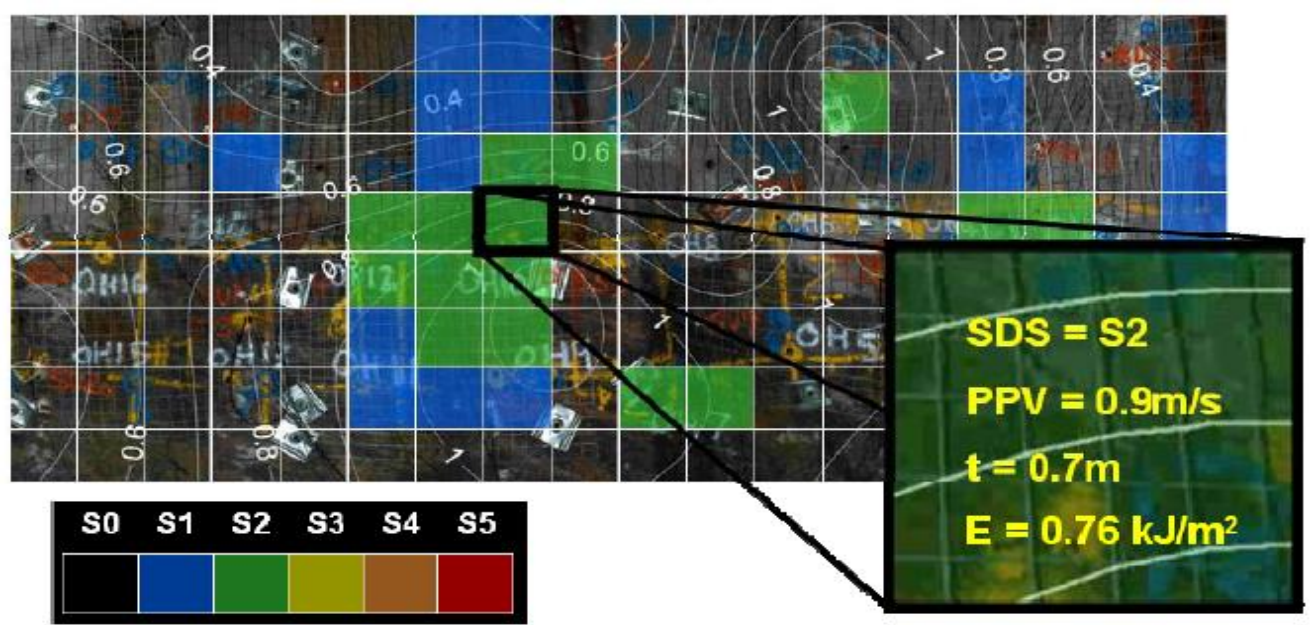

Figure 8 Simulated rockburst test ppv versus seismic damage, (ACG 2008)

A comparison of the performance of HEA Mesh compared to the other test ground support system in energy absorption is shown in Figure 9.

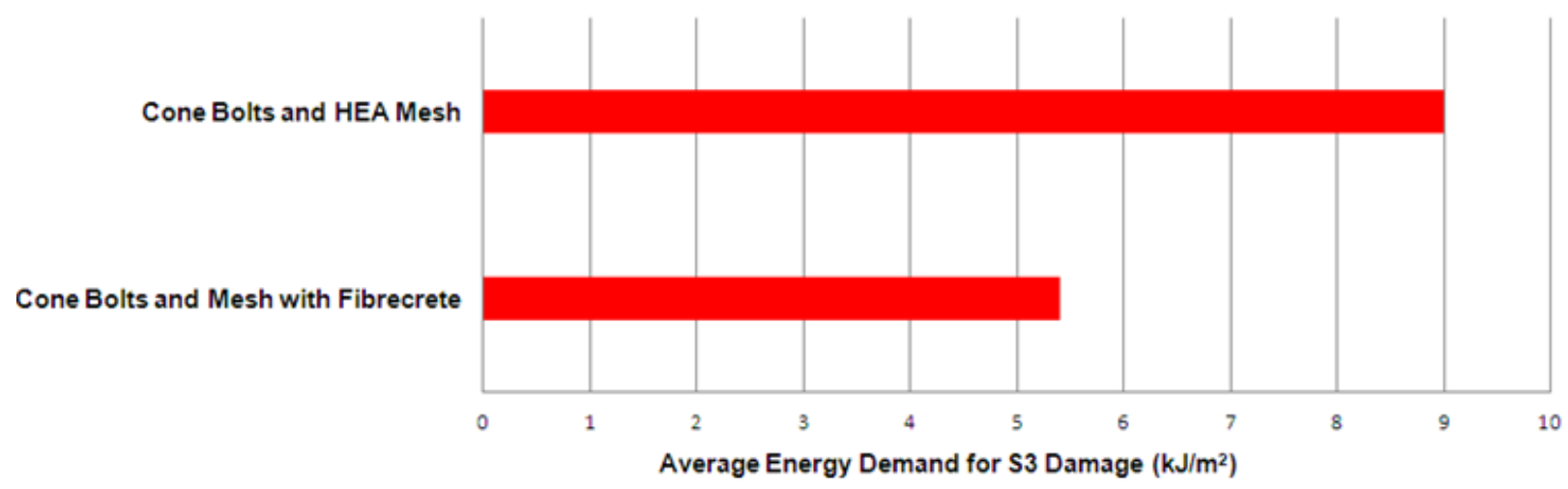

Figure 9 Comparison of S3 energy demand for test ground support in the simulated rockburst test

In conclusion:

- For this specific test, the cone bolts and HEA Mesh absorbed $60 \%$ more energy than cone bolts, fibrecrete and mesh, for the equivalent moderate damage.

- The surface support with HEA Mesh is no longer the weakest link.

- Optimising the rockbolt system for HEA Mesh is likely to further increase performance of the overall ground support system (refer to cone bolts fully pulled out by the test).

- Additionally, for this specific test, fibrecrete was eliminated from the ground support utilising HEA Mesh and outperformed the dynamic support using fibrecrete. 


\section{Data}

\subsection{Australian underground mine site data collation}

Fifty currently operating Australian underground mine sites were able to be identified and were used as a sample population for this study. Each mine site was categorised in terms of general excavation response, which are summarised below, and mines were categorised in Figure 10.

Severe squeezing ground and rockbursting conditions are categorised as having separate incidences of squeezing ground and rockbursting damage to workings which causes complete loss of functionality of ground support more than once per quarter.

Moderate squeezing ground and rockbursting conditions are categorised as having separate incidences of squeezing ground and rockbursting damage to workings which causes complete loss of functionality of ground support once or more between three months and a year.

Minor squeezing ground and rockbursting conditions are categorised as having squeezing ground and rockbursting damage to workings which causes complete loss of functionality of ground support more than once per year.

Mining operations which experience some degree of rockbursting, spalling pillars or squeezing ground make up approximately $34 \%$ of the Australian study sample population and are potential customers for the HEA mesh.

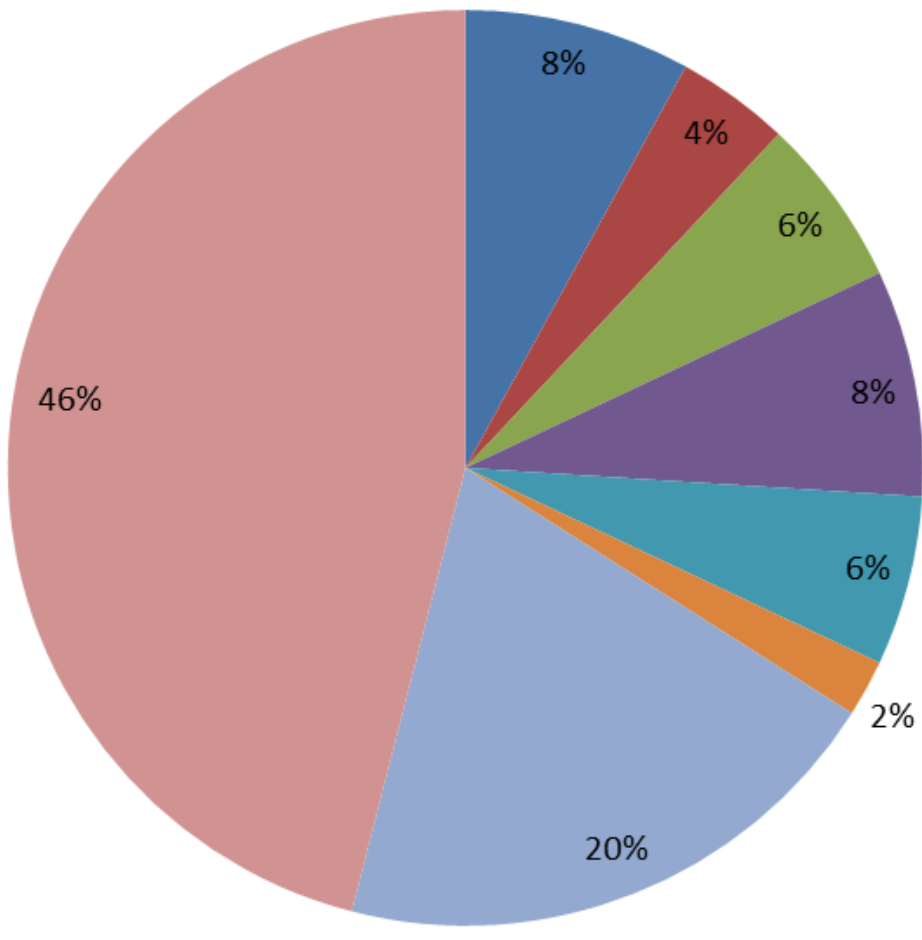

- Severe squeezing ground and rockbursts

— Severe squeezing ground

Moderate rockbursts and squeezing ground

- Moderate squeezing ground

noderate rockbursts

- Minor rockbursts

n Good ground conditions

- Unknown ground conditions

\section{Figure 10 Australian underground mine general excavation response conditions}

\section{$3 \quad$ Methodology}

\subsection{Mine site case studies}

The ground support costs were collated and analysed for two mines sites from Australia and one from overseas with high stress, seismic conditions. These costs were sourced from the mines sites and their suppliers. Mine Sites A and B are in Australia, Mine Site $C$ is overseas. These mine sites are assumed to be a representative sample population in terms of cost and efficiency. 
Australian Goods and Services Tax (GST) was not included in the costs. Freight, labour, equipment and equipment maintenance, and time taken to undertake the ground support task costs were included.

For comparison, the HEA Mesh is costed as a replacement for weld mesh and fibrecrete in the current case study mine seismic ground support systems. Additionally, a comparative cost for substituting the HEA Mesh and dynamic rockbolts is also shown.

The weighted average ground support costs per metre is the ground support cost applied over the individual mine site development metres per month.

\subsection{Fibrecrete}

Fibrecrete costs can be estimated per square metre of the excavation. The cut length is multiplied by the width. This surface area is multiplied by the fibrecrete thickness required, typically between $50-100 \mathrm{~mm}$. An allowance of $10-20 \%$ rebound losses with a further $10-20 \%$ to account for the roughness of the excavation.

The excavation surface area depends on the cut length, excavation roughness, profile shape (shanty-back, full arch, slight arch, square, etc.), over-break and under-break.

\subsection{HEA Mesh and rockbolts}

The number of bolts required per sheet of HEA Mesh per metre advance varies according to the excavation dimensions and required height of mesh from the floor. Bolts must be placed where the supplier has recommended in order for the HEA Mesh to work to its full capacity. At minimum, the supplier recommends the HEA Mesh to be pinned in each corner, in the centre and on the mid-points from the corners on the edge of the sheet. As the sheet dimensions required at each mine site may change, and the individual mine site bolt spacing requirement also differ, there are no minimum bolt spacings required for usage with the HEA Mesh.

\section{$4 \quad$ Results}

A summary histogram of the squeezing ground and seismic ground support standard costs of the three case study mine sites is presented in Figure 11. The different ground support standards for high stress and squeezing ground are arbitrarily named GS1 to GS10. Figure 12 displays the percentage decrease in ground support costs per metre advance when HEA Mesh is incorporated into the ground support system, and one layer of fibrecrete is removed. This resulted in an average of $38 \%$ costs savings per metre advance.

Table 1 illustrates the weighted average of the high stress and squeezing ground ground support standard costs from each mine, the cost benefit which each mine site can expect when adopting the HEA Mesh, reducing fibrecrete and using the complementary dynamic tendon support. Theoretically a significant cost savings per month result for all three mine sites, of between 16 and $59 \%$ reduction in ground support costs per month, per metre of advance.

The calculations show that in the mine site case study sample population, theoretically all HEA Mesh equivalent ground support regimes are substantially less expensive than the currently utilised ground support standards, where fibrecrete was omitted or reduced in quantity. 


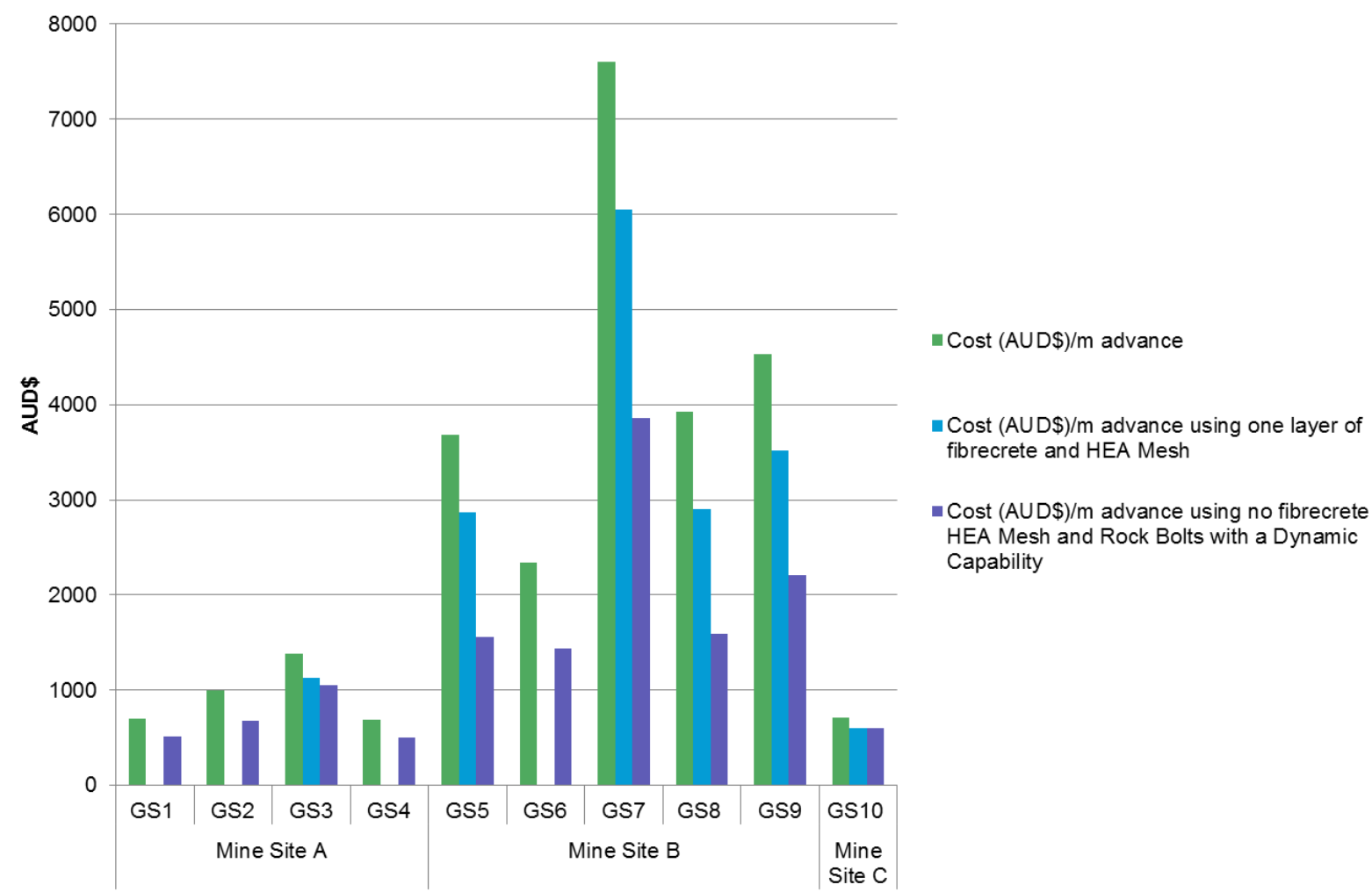

Figure 11 Summary histogram of case study mine site high stress and squeezing ground and HEA Mesh comparative costs

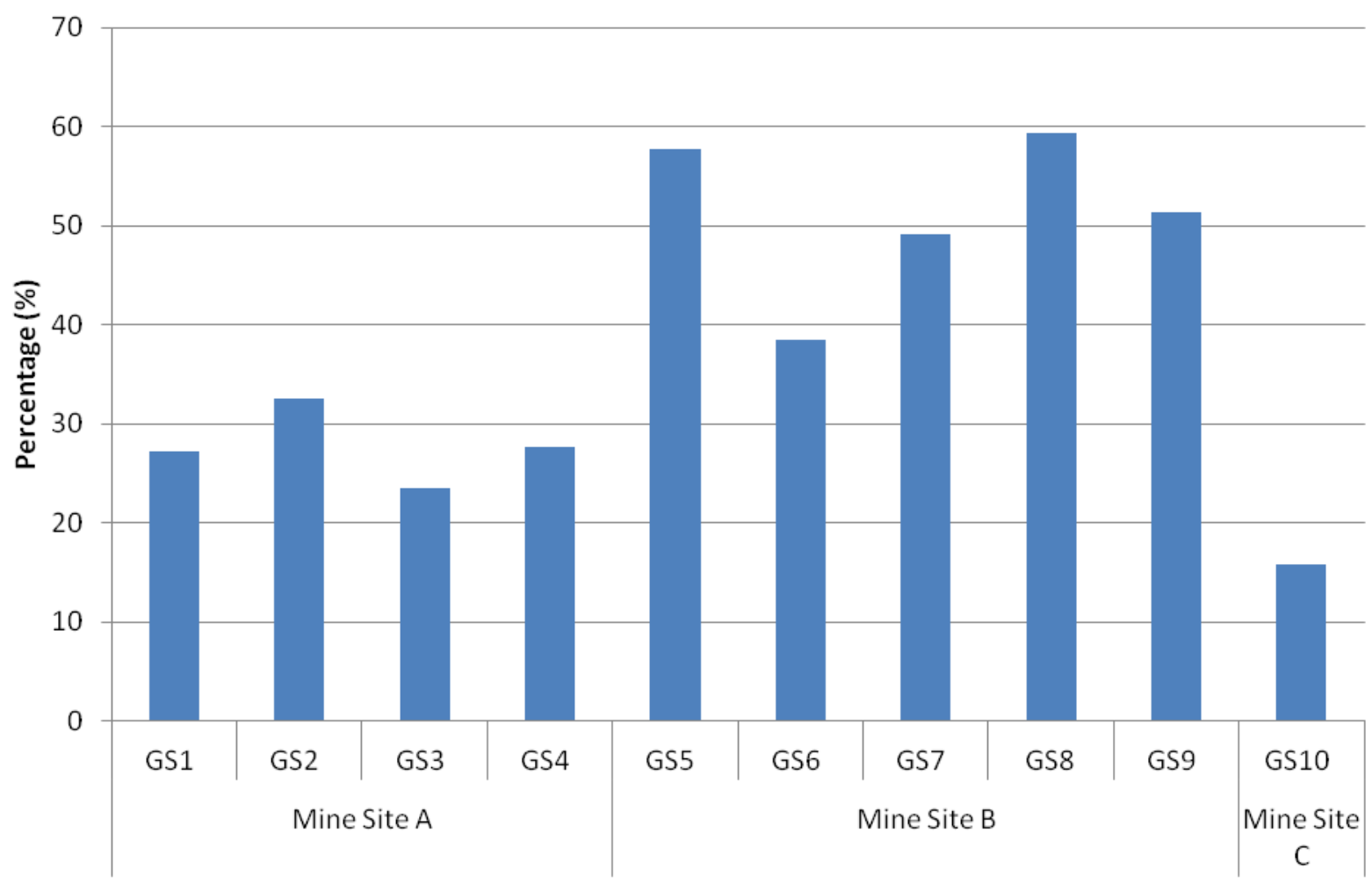

Figure 12 Cost percentage decrease (AUD\$/m) Substituting HEA Mesh and removal of one fibrecrete layer 


\section{Table 2 Mine sites HEA Mesh incorporated equivalent ground support cost savings} weighted average

\begin{tabular}{|c|c|c|c|}
\hline & $\begin{array}{l}\text { Weighted average } \\
\text { Ground support cost/m } \\
\text { (AUD) }\end{array}$ & \% Savings & $\begin{array}{c}\text { Savings per } \\
100 \text { m advance } \\
\text { (AUD) }\end{array}$ \\
\hline \multicolumn{4}{|c|}{ Mine site A } \\
\hline Total - GSx & 837 & & \\
\hline $\begin{array}{l}\text { Total - HEA Mesh } \\
\text { (no fibrecrete) }\end{array}$ & 603 & $28 \%$ & 23,353 \\
\hline $\begin{array}{l}\text { Total - HEA Mesh } \\
\text { including D-Bolts }\end{array}$ & 613 & $27 \%$ & 22,399 \\
\hline \multicolumn{4}{|c|}{ Mine site B } \\
\hline Total - GSx & 4,061 & & \\
\hline $\begin{array}{l}\text { Total - HEA Mesh } \\
\text { (1 layer fibrecrete) }\end{array}$ & 3,081 & $24 \%$ & 98,022 \\
\hline $\begin{array}{l}\text { Total - HEA Mesh } \\
\text { (no fibrecrete) }\end{array}$ & 1,900 & $53 \%$ & 216,136 \\
\hline \multicolumn{4}{|c|}{ Mine site C } \\
\hline Total - GSx & 712 & & \\
\hline $\begin{array}{l}\text { Total - HEA Mesh } \\
\text { (1 layer fibrecrete) }\end{array}$ & 600 & $16 \%$ & 11,258 \\
\hline $\begin{array}{l}\text { Total - HEA Mesh } \\
\text { (no fibrecrete) }\end{array}$ & 604 & $15 \%$ & 10,847 \\
\hline
\end{tabular}

\section{$5 \quad$ Conclusions}

Many theoretical advantages of installing HEA Mesh for dynamic or high stress ground conditions have been identified in this paper.

Some $34 \%$ of the Australian underground mine sites identified in the study sample population have some degree of seismicity and above the average rock stress magnitude for that region, where HEA Mesh would be appropriate. The HEA Mesh has also had an installation trial with positive results, and has the same installation time as a sheet of weld mesh.

In rockburst simulation field trials, the HEA Mesh with dynamic bolts performed better than the combination of weld mesh, dynamic bolts and fibrecrete, thus improving mine safety while also having the potential to reduce rockburst damage rehabilitation costs.

Potentially significant ground support cost savings may be achieved when HEA Mesh is used and fibrecrete is reduced, on average $38 \%$ per metre advance. A weighted average of all high stress and squeezing ground ground support costs over the mine site case study development metres per month has a cost saving of between 16 and $59 \%$.

In theory, in the case of a single headed development, elimination of fibrecrete application and curing time will result in significant time savings. Installation utilises the jumbo drill rig which is the most common machine owned and used by underground mining operations for the installation of mesh and bolts, expenditure on new equipment would not be required. 
The HEA Mesh sheet can be made to any size specification required, although the resulting bolting pattern needs to be taken into consideration, and there are research and development tax incentives for operations in the initial stages of trialling the HEA Mesh.

The costing analyses demonstrates that theoretically, when HEA Mesh was substituted into current ground support standards at three different mining operations, and the fibrecrete cycle is reduced or omitted, that there are potential considerable cost savings to be obtained in all cases.

The HEA mesh has the required dynamic capacity and has the potential to replace more conventional support systems and be more cost efficient. Further underground trials to assess the real cost associated with this product are needed before a definite cost saving conclusion can be reached.

\section{Acknowledgement}

The author thanks Mark Heap of Coffey and Tom Schnepple from The University of Western Australia, and to the many mine sites and suppliers which contributed their data to this study.

\section{References}

Australian Centre for Geomechanics 2008, Long Shaft Site 3 Simulated Rockburst Results, report from the Mine Seismicity and Rockburst Risk Management Project, ACG, Perth.

Hadjigeorgiou, J, Karampinos, E, Turcotte, P \& Mercier-Langevin, F 2013, 'Assessment of the influence of drift orientation on observed levels of squeezing in hard rock mines', in Y Potvin \& B Brady (eds), Proceedings of the Seventh International Symposium on Ground Support in Mining and Underground Construction, Australian Centre for Geomechanics, Perth, pp. 109-118.

Heal, D 2010, 'Observations and Analysis of Incidences of Rockburst Damage in Underground Mines', PhD thesis, The University of Western Australia, Perth.

Kaiser, PK, Tannant, DD, McCreath, DR \& Jesenak, P 1992, 'Rockburst Damage Assessment Procedure', in PK Kaiser \& DR McCreath (eds), Rock Support in Mining and Underground Construction, A.A. Balkema, Rotterdam, pp. 639-647.

Kaiser, PK \& Cai, M 2013, 'Critical review of design principles for rock support in burst-prone ground - time to rethink!', Y Potvin \& B Brady (eds), Proceedings of the Seventh International Symposium on Ground Support in Mining and Underground Construction, Australian Centre for Geomechanics, Perth, pp. 3-38.

Morton, EC, Thompson, AG, \& Villaescusa, E 2009, 'The performance of mesh, shotcrete and membranes for surface ground support', in M Diederichs \& G Grasselli (eds), Proceedings of the 3rd CANUS Rock Mechanics Symposium: ROCKENG09, paper 4022.

Potvin, Y \& Hadjigeorgiou, J 2008, 'Ground Support Strategies to Control Large Deformations in Mining Excavations', The Journal of the Southern African Institute of Mining and Metallurgy, vol. 108, pp. 393-400.

Stacey, TR and Ortlepp, WD 2001 'Tunnel surface support - capacities of various types of wire mesh and shotcrete under dynamic loading', Journal of the South African Institute of Mining and Metallurgy, vol. 101, no. 7, pp. 337-342. 